\title{
Pentecostalism in Tension
}

A diversification of Argentina's religious field has led to the emergence and expansion of a number of religious options. The religious diversification process offers individuals the possibility to choose between a great number of religious options. At the same time, more and more Argentineans take advantage of this possibility and choose a religious option other than Catholicism. Yet, not all religious options are perceived as equally appropriate. Catholicism remains the most legitimate religious option, whereas some of the deviating options suffer from a low level of perceived legitimacy. Despite its low legitimacy, Pentecostalism has experienced a vast expansion primarily in the lower class. The present chapter gives an overview of Argentina's Pentecostal movement and explores its relationship to the middle class. It will thereby stress in particular the "objective" class position and symbolic status of Pentecostals in Argentina. Exploring the objective class position and symbolic status of themovement, I will reconstruct the tensions between Pentecostalism and the representations of the middle class.

In order to address these topics, the chapter is split into different sections. The first section highlights different aspects of Argentina's Pentecostal movement. It examines the diversity and the unifying institutions of the Pentecostal movement as well as its reputation in Argentinean society. The second section studies the social stratification of its membership and its lack of middle class appeal. The lower class bias of Pentecostalism is explained by a mismatch between Pentecostalism and the representations of the middle class. This mismatch creates a threshold which exacerbates middle class conversions to the movement. Whenever middle class actors become Pentecostal despite this mismatch, they may face tensions in their social environment. These tensions are described in the last section of the chapter.

5.1 Argentinean Pentecostalism between Diversity, Unity and Stigmatization

\subsubsection{Religious Diversity and Competition in Argentinean Pentecostalism}

Today, Pentecostalism is the most influential non-Catholic religious group in Argentina and has become a serious competitor of the Catholic Church. ${ }^{1}$ Around

1 Algranti 2007b: 27; Saracco 1989: 309.

(C) JENS KOEHRSEN, 2016 | DOI 10.1163/9789004310148_006

This is an open access chapter distributed under the terms of the Creative Commons Attribution-

Noncommercial 3.0 Unported (CC-BY-NC 3.0) License. 
eight percent of the Argentinean population is estimated to be Pentecostal. ${ }^{2}$ However, Argentinean Pentecostalism does not constitute a uniform movement. In fact, the movement is highly fragmented and embraces a considerable variety of religious styles, a variety that the simple distinction between NeoPentecostalism and traditional Pentecostalism cannot capture. ${ }^{3}$

In the absence of a central and unifying institution, Pentecostal churches can combine different aspects of Pentecostalism. For instance, some churches embrace prosperity gospel but disregard spiritual warfare, whereas others emphasize the gifts of the Holy Spirit and spiritual practices such as faith healing and exorcisms. Some churches adhere to a conservative moral which obligates women to wear dresses and men to dress in suits, while other congregations are rather liberal and try to empower women for emancipation. Differences are also evident in the music. Some congregations prefer Latin American rhythms (such as cumbia), whereas others play emotional rock and pop, and still others tend towards classical music and hymns. Each church can create its own Pentecostal identity, adapting and combining different religious styles.

Therefore, in and around Buenos Aires one can observe an enormous variety of Pentecostal churches. ${ }^{4}$ In terms of their size, churches can be classified into four categories: mega, large, medium, and small churches. Most of the

2 See Conicet 2008. Wynarczyk (2010: 18) estimates that between $10 \%$ and $13 \%$ of the Argentinean population is Protestant. Gooren (2010b) referring to Espinosa (2004) states that $11 \%$ of Argentineans are Pentecostal. Anderson (2004: 68) supposes that even 19\% of the Argentinean population is Charismatic (probably including Catholic Charismatics). Unfortunately, Anderson does not mention any data source. Barrett et al. (2001(1): 72) estimate the number of Pentecostals/Charismatics in Argentina at 8.4 million representing $22.7 \%$ of the Argentinean population in the year 2000. This number also includes Charismatic Catholics. This is also illustrated by the proportion of Catholics in the entire Argentinean population which is estimated at $91.2 \%$. The proportion of Protestants is at the same time estimated at $6.2 \%$. According to these estimations the number of non-Catholic Pentecostals has to lay significantly below $10 \%$, probably even below $5 \%$.

3 Neo-Pentecostalism is usually associated with spiritual warfare and prosperity gospel. Yet, many churches which conduct spiritual warfare reject - at least officially - prosperity gospel and vice versa. This raises doubts about the appropriateness of the distinction between traditional Pentecostalism and neo-Pentecostalism. Moreover, many Pentecostal churches have adapted to some of the neo-Pentecostal characteristics: the use of mass media, prosperity gospel, spiritual warfare or post-millenarism. Spiritual warfare and prosperity gospel are widespread in today's Pentecostalism and can even be found empirically in Pentecostal branches which are generally conceived of as traditional Pentecostals (Míguez 1998: 61-62, 68-69; Semán 2001b: 148).

4 It is difficult to estimate the number of Pentecostal churches in the urban area of Buenos Aires since only a small number of them are registered in the registro. In 1992 there were 120 
churches in Buenos Aires are, of course, small and medium-sized churches while the number of large and mega churches is limited.

Mega churches are churches with a total attendance of more than 2000 at Sunday services, while large churches attract between 800 and 2000 to their Sunday church services. The most important among them are Rey de Reyes, Catedral de la Fe, Presencia de Dios, Centro Cristiano Nueva Vida, Iglesia Universal del Reino de Dios, Iglesia del Puente in Quilmes, and perhaps Manatial de Bendiciones in Partido San Martin. ${ }^{5}$ The success of most of these churches depends strongly on the charisma of their main pastor. Pastors have become important figures in Argentinean Pentecostalism. This is particularly the case for Claudio Freidson from Rey de Reyes and Pastor Osvaldo Carnival from Catedral de la Fe who today are common names among Pentecostals in and outside of Argentina. Their churches are today the largest Pentecostal churches in Buenos Aires. Rey de Reyes, for instance, is estimated to have more than 20.000 members. ${ }^{6}$

The central branches of the large and mega churches have at their disposal colossal main halls with up to 3000 seats and normally include other facilities like cafeterias, bookstores, seminar rooms, and in some cases even multi-storey car parks. Not only do they have a highly developed infrastructure but also

registered Pentecostal churches alone in the city of Buenos Aires (Wynarczyk et al. 1995: 9). This number does not include those churches that are not registered. Nevertheless, one can try to calculate a very rough estimation of the number of churches in Greater Buenos Aires based on different conditions: the city of Buenos Aires has around 3 million inhabitants while Greater Buenos Aires has approximately 12 million inhabitants. At the same time, the percentage of Pentecostals is supposed to be higher in the poorer areas outside the city of Buenos Aires: while the percentage of Pentecostals in the city can be estimated at around $5 \%$, there are around $20 \%$ of Pentecostals in lower class districts. One may suppose an average Pentecostal population of $15 \%$ in Greater Buenos Aires. Thus, the amount of Pentecostal churches per inhabitant is (at least) three times higher than in the city. At the same time, the population is around four times higher than in the city of Buenos Aires. Consequently, it can be supposed - not including the non-subscribed temples in the city in 1991 - that the number of temples was $120 \times 3 \times 4=1440$ in 1991. This is a rather low estimation since it does not include the churches that were not registered in Buenos Aires City and disregards a potential increase in the quantity of Pentecostal churches between 1991 and today. Hence, one may estimate that the number of Pentecostal temples in Greater Buenos Aires is at least 1500, but probably significantly higher than 2000.

5 See for Rey de Reyes Algranti 2010; for the Iglesia Universal Reino de Dios (IURD) in Argentina Semán 2003; Semán and Moreira 1998; Semán and Oro 2000; for the IURD in general Corten et al. 2003; Freston 1995: 129-132; 1999: 153-16o; Luca 2008b: 230-236, 248-251; Ruuth 2001.

6 See Algranti 2010:101. 
generally offer a variety of church services, church groups and other activities (workshops etc.) to their members. Besides the main temple, these churches usually have smaller branches called annexos in different suburbs of Greater Buenos Aires and across the country and sometimes abroad.

Although the majority of their members are still from the lower class, large and mega churches like Rey de Reyes and Cathedral de la Fe attract a diversity of social sectors: one can find among their members individuals from the shantytowns and poorer suburbs as well as from the urban middle class. These churches appear to be able to attract different social classes by embracing a variety of religious styles. In these churches, individuals can "consume" numerous religious "goods" of different religious styles - such as different groups, courses and church services. ${ }^{7}$ Each member can choose from this variety of styles the one that most fits his/her personal preferences. ${ }^{8}$ Due to their public visibility and impact, mega and large churches are common reference points among Argentinean Pentecostals. However, in terms of absolute numbers, smaller and medium-sized churches are more important since the vast majority of Pentecostals in Argentina are members of these churches.

There are plenty of medium-sized churches in Greater Buenos Aires. These congregations attract between 100 and 800 participants to their Sunday church services. Many branches of the Asambleas de Dios (AD) and Unión de las Asambleas de Dios (UAD) fit into this category. The infrastructure, organization and style of church services vary greatly among medium-sized churches. Some medium-sized churches offer a wide variety of courses and church groups and even contain educational facilities such as kindergartens and primary schools, whereas other churches are supported by a much less developed infrastructure.

7 In Rey de Reyes, for instance, there are specific groups that focus on young academics, students and professionals. Moreover, there are courses that coach leadership skills to members and prepare young individuals for a professional career. At the same time the church offers courses which provide basic education to adults from less privileged social backgrounds. The style of worship varies from more sober church services to highly emotional church services including faith healing and testimonies of miracles. Smaller churches, instead, cannot offer such a variety. Nevertheless, some well-organized medium-sized churches can still embrace different offers and religious styles. Yet, the differences in style will be less pronounced and rather limited.

8 The internal diversity of large and mega churches renders it difficult to attribute a general style to these churches. Therefore, I focus on small and medium-sized churches which are to a much lesser degree able to embrace different styles and tend to attract preferentially one social sector. 
Finally, there are numerous smaller Pentecostal churches which attract up to one hundred members to their Sunday church services. These churches represent the majority of Pentecostal churches in Greater Buenos Aires. Most of these tiny churches are situated in the poor suburban areas of Buenos Aires. Their infrastructure and organization stand in contrast to that of the mega churches. Usually they are the size of a small saloon where between ten and fifty people meet every week for worship. They are often poorly furnished and depend heavily on donations from their community. Sometimes they lack basic facilities such as toilets and running water. Most of them are grassroots churches which appear and disappear overnight. They frequently emerge from rifts in other churches when a group of members splits off and founds their own church. ${ }^{9}$

The plurality of churches creates a manifold Pentecostal "market". Individuals can choose between a vast variety of Pentecostal churches and styles. By affiliating themselves with a church they choose a specific style of Pentecostalism. However, religious switching is frequent among Pentecostals. Even though actors decide on one church and style at one moment in their life, they may change their opinion after a time and later join a different church. Many Pentecostals switch their church every three or four years. In some cases Pentecostals move constantly between two or more churches, combining the religious styles of these congregations. ${ }^{10}$

At the same time, Pentecostal churches seek constantly to recruit new members. They are in constant struggle with one another for the favor of devotees. The reasons are obvious: they depend on their members. The more members they acquire, the more financial and organizational resources and status they gain. Moreover, expanding churches enjoy the reputation of being particularly blessed. They are considered to be churches in which the Holy Spirit acts in a remarkable way. Thus, expansion contributes to their status among Pentecostals and can promote further expansion. ${ }^{11}$ However,

9 See Frigerio 1999: 75-76; Séman 2000: 161; 2006a: 199-202.

10 Despite being affiliated with a specific church many Pentecostals visit other churches from time to time. Pentecostals are generally familiar with a wide range of different churches. Thus, the religious search may continue within the field of Pentecostalism (see also Algranti and Bordes 2007).

11 There are exceptions in which the positive relationship between a rising number of adherents and the status of a church is not valid. One example is the Universal Church of God which despite its high number of adherents suffers a poor reputation among Pentecostals. 
also a strong sense for proselytism among Pentecostals contributes to this struggle for souls. ${ }^{12}$

Hence, churches will under normal circumstances try to expand and gain as many members as possible. They apply different strategies to do so. Some churches have developed marketing strategies and use different types of media like flyers, books, radio programs, internet platforms and sometimes even TV programs. Sometimes they organize evangelical events, distribute flyers, and preach in streets and squares. However, the strongest medium of expansion remains personal networks. ${ }^{13}$ Most new visitors arrive at churches due to a personal contact with members. They are invited by friends, relatives, or neighbors who are already members of the church. Yet, only a proportion of those who visit a church the first time will join it. Whether they become members of this particular congregation is a matter of their religious choice: they can decide to affiliate with the church, or to join another or no Pentecostal church.

\subsubsection{Unifying Institutions and the Formal Circle of "Evangelical Protestantism"}

Despite the diversity of Pentecostalism and evangelical Protestantism in Argentina, there are several institutions which aim to unify and represent Pentecostalism and evangelical Protestantism: evangelical and Pentecostal umbrella organizations, inter-congregational Biblical seminaries, evangelical mass events, and evangelical magazines facilitate the construction of a common identity for the evangelical movement in Argentina to which people often refer as "los evangelistas". ${ }^{14}$ Yet, some of these institutions do not only help to create a shared image of evangelical Protestantism but also constitute a formal and exclusive circle of evangelical Protestantism. ${ }^{15}$ This circle does not represent the whole movement, but rather only a - mostly middle class - fraction of it, as will be shown later.

The historical evolution of Protestantism in Argentina has led to the development of several umbrella organizations which seek to represent Protestantism in Argentinean society. The most important umbrella organizations for

12 The task of gaining and rescuing as many souls as possible for the kingdom of God forms a central aim of the Pentecostal movement. The efforts and the success in accomplishing this aim may be measured in the size and expansion rates of a congregation.

13 See, for instance, Algranti 2010: 151-152,; Míguez 1998: 51-52.

14 See, for instance, Marostica 1994: 8.

15 Algranti (2010: 84-85) describes a formal circle of Pentecostalism which is defined by affiliation to one of the umbrella organizations and registration in the Registro Nacional de Culto. 
Pentecostal churches are FECEP (Federación Confraternidad Evangélica Pentecostal), ACIERA (Alianza de Iglesias Evangélicas de la República Argentina) and to a minor degree FIPA (Federación de Iglesias Pentecostales Argentina). ${ }^{16}$ These organizations try to establish formal standards and represent Pentecostalism and evangelical Protestantism vis-à-vis politics and the public sphere. Different objectives shape the agenda of these umbrella organizations: improving the image of evangelical Protestantism, gaining formal recognition, providing a public voice to the movement, facilitating the exchange between congregations and pastors, establishing a type of accountability, and influencing the public agenda concerning moral topics such as abortion and same-sex marriage. ${ }^{17}$ Thus, organizations like ACIERA and FECEP together with other Protestant umbrella organizations like FAIE ${ }^{18}$ engage in political and legal campaigns to gain formal recognition from the state. Their principal goal appears to be to improve the acceptance of the movement within the religious and public spheres in order to become a respectable and legitimate religious option which can compete in terms of legitimacy at eye level with the Catholic Church. ${ }^{19}$

Pentecostal churches can apply for membership in these organizations. Although membership is generally granted to churches that apply, acceptance of the application is not guaranteed. The IURD, for instance, applied for membership and was rejected by ACIERA and FECEP. ${ }^{20}$ Membership in FECEP or ACIERA can serve as certificate and seal of approval suggesting that churches affiliated with them meet certain formal standards. Therefore, membership in

16 While FECEP and FIPA are genuine Pentecostal umbrella organizations, ACIERA represents Pentecostal churches as well as other Protestant churches from the evangelical wing, for instance Baptist churches. ACIERA is often also called FACIERA. Among these umbrella organizations, FECEP is the one that represents the highest number of Pentecostal churches. FIPA particularly represents smaller Pentecostal churches which embrace only one or two congregations (Wynarczyk 2009a: 61-63; Wynarczyk et al. 1995: 10-11). Besides these three organizations which represent rather the Biblical fundamentalist wing of Protestantism, there is also an organization which represents historical (liberal) Protestantism called faie (Federación Argentina de Iglesias).

17 Interview Pastor Pedro, Part 2; Part 3. These organizations have served also as a legitimation strategy in the context of the anti-sect discourse (Wynarczyk et al. 1995: 11).

18 FAIE - Federación Argentina de Iglesias Evangélicas - is traditionally the umbrella organization which assembles the historically Protestant churches of Argentina. Nevertheless, today there are also some Pentecostal churches integrated in FAIE.

19 See also Frigerio 1998: 447; Maristoca 1994; Wynarczyk 1994.

20 Access to these organizations is not as easy as it may seem. Applicants for an ACIERA membership, for instance, have to be nominated by two member churches. Thus, 
these organizations becomes a form of capital which raises the credibility of a church. Churches, on the other hand, which are not affiliated with one of the umbrella organizations are excluded from the circle of formally recognized churches and may suffer a low degree of legitimacy. ${ }^{21}$ Hence, umbrella organizations exercise a significant degree of power since they are in the position to formally designate which church is a "decent" evangelical church and which not. Numerically, however, the umbrella organizations represent only a fraction of the Pentecostal movement since the majority of smaller churches are not affiliated with these bodies.

Another important umbrella organization for evangelical churches in the city of Buenos Aires is the Consejo de Pastores de la Ciudad de Buenos Aires (consejo). This council forms a network of evangelical pastors from the city of Buenos Aires who meet on a regular basis to organize events and develop expansion strategies. ${ }^{22}$ Besides the umbrella organizations, there are other institutions which unite the Pentecostal community to some degree: Biblical seminaries, news magazines, and mass events. Although many of the larger churches have their own Biblical seminaries, there are some seminaries which are intercongregational and enjoy an excellent reputation among Pentecostals. These institutions offer theological degrees to future pastors and courses to lay members who are simply interested in studying theology. The most important among them are the Instituto Biblico Rio de la Plata and Seminario Biblico de Fe. ${ }^{23}$ Yet, not every Pentecostal pastor in Argentina has received a formal theological education.

churches who want to join ACIERA require contact with other churches that are already affiliated with this umbrella organization (Interview Pastor Oscar Part 1/2). Moreover, church leaders must know and care about the affiliation and require the necessary bureaucratic skills and knowledge to manage the enrolment procedure. After having received membership status in one of these umbrella organization congregations, churches can still lose their membership status. A prominent case is the church Ondas de Amory Paz which was expelled from FECEP and ACIERA after its pastor, Hector Gimenez, suffered several public scandals (Interview Pastor Nicolás).

21 See Algranti 2007a: 114; 2010: 84-85.

22 Councils of this type exist theoretically also in different areas of the province of Buenos Aires and are separated into different geographical districts. The council of the city of Buenos Aires is, however, particularly interesting due to its outstanding degree of activity and cooperation between pastors and due to the fact that it forms an important instrument for the coordination between evangelicals in the city of Buenos Aires. Many of the pastors organized in the consejo of the city of Buenos Aires cultivate strong friendships and also engage in direct cooperation between their churches.

23 Three of the most famous Pentecostal preachers, Claudio Freidson, Osvaldo Carnival and Guillermo Prein, studied in the Instituto Biblico Rio de la Plata (Algranti 2010: 86). Besides 
Many pastors, especially those from the smaller churches in the suburbs, have not attained any type of (formal) theological education. The presence or absence of theological education in the pastoral body is another characteristic which distinguishes the formal circle of evangelical Protestantism. There are two important magazines for the evangelical community in Argentina: El Puente and La Corriente del Espiritu. ${ }^{24}$ These magazines form part of a bigger evangelical media industry which consists of publishers, distributors, TV and radio channels, TV producers, music labels, and event managers. ${ }^{25}$

Finally, inter-congregational evangelical mass events constitute another mechanism which unifies evangelical Protestantism and Pentecostalism. Historical examples are the campaigns of Tommy Hicks and Carlos Annacondia which facilitated the development of a national evangelical

these two Pentecostal seminaries, there is a variety of institutions that also offer educational training to evangelicals like the IBA, the Seminario Bautista, the FIETT and the ISEDET. Despite also attracting Pentecostal students, these institutions do not necessarily focus on Pentecostal students. The ISEDET, for instance, is one of the main institutions for the training of pastors of historically Protestant churches. Interestingly, the Pentecostal seminaries do not offer degrees that are officially recognized by the Argentinean state. Officially recognized degrees in theology can be only acquired from the ISEDET and the Seminario Bautista.

24 La Corriente del Espiritu is a monthly magazine which is dedicated particularly to the Pentecostal community and is distributed in many Pentecostal churches. Instead, El Puente is a magazine for the wider evangelical public, but also focuses - due to the predominance of Pentecostals in Argentina - mainly on the Pentecostal movement. El Puente and other publications from the same evangelical media group can be acquired at newsstands around the country. Besides El Puente there are other magazines published by the same agency: a magazine focusing on women called Fem and a magazine which focuses on the youth and young adults called Conexiones. El Puente appears on a monthly basis and includes news, announcements concerning the Protestant community, as well as articles about different topics about the Christian faith. The magazines are closely related to the umbrella organizations mentioned above. El Puente, for instance, dedicates at least two pages to official announcements from the FECEP, ACIERA, and FIPA in each of its releases. Moreover, the articles published in the magazines tend to be from pastors associated with the umbrella organizations.

25 See Algranti 2007a: 123; Marostica 1994: 10-12. Besides TV and radio channels, there also exists a range of famous national music acts closely associated with evangelical Protestantism such as, for instance, Rescate. The research has not placed a specific focus on Pentecostal radio and TV productions since they have no major stake in the construction of the formal circle of Pentecostalism and the boundary work of middle class Pentecostalism in Argentina. 
identity. ${ }^{26}$ Another more recent campaign, for instance, took place during several days in 2008 in downtown Buenos Aires. Luis Palau and famous Latin American artists performed at this event in front of approximately one hundred thousand people. ${ }^{27}$

These institutions - umbrella organizations, Biblical seminaries, intercongregational evangelical mass events, magazines and other media - help generate a common identity and formalize evangelical Protestantism. They assume the role of publicly representing evangelical Protestantism and thereby allow evangelicals from different denominations to identify themselves as part of the same movement, as well as to transmit the image of a unified movement to the rest of society, often referred to as "los evangelistas". Yet, the entire movement does not participate in these unifying institutions. Many Pentecostal churches are excluded from these unifying institutions. Therefore, the institutions form at the same time a mechanism of exclusion which leaves a wide range of churches out of the circle of institutionalized evangelical Protestantism and Pentecostalism. The churches and pastors engaged in these institutions represent only a fraction - probably a minority - of the whole movement and are dominated by middle class Pentecostals, as will be further discussed below.

\subsubsection{From Dangerous Sects to Tolerable Deviations: The Public Image of Pentecostalism}

Despite the attemptstolegitimizeand improve the publicimage of Pentecostalism, its relationship with Argentinean society is still ambivalent. Many of the remaining reservations and prejudices go back to the anti-sect discourse of the $1980 \mathrm{~s}$ and 1990 .

Particularly at the beginning of the massive expansion in the 1980s and 1990s, Pentecostal churches were perceived as problematic sects. This perception was nourished by media debates describing the rise of new religious movements as an invasion of sects. Alfredo Silletta's (1986) famous publication "Las sectas invaden la Argentina" which became a bestseller in Argentina contributed to this vision. ${ }^{28}$ The success of his book helped spread an image of new religious movements as dangerous sects and transformed Silletta into a famous "sect-expert" frequently consulted by the media and even by the Argentinean state. ${ }^{29}$

\footnotetext{
26 Saracco 1989: 307-308; Algranti 2007b: 26.

27 See Giménez et al. 2008.

28 Silletta 1986.

29 Frigerio 1993b; Wynarczyk 2009a: 194-197.
} 
Due to its outstanding success, the Pentecostal movement became one of the preferred topics of the anti-sect discourse. The presence of Pentecostal churches on Argentinean soil was initially regarded as an invasion of foreign interests and an expression of us imperialism. ${ }^{30}$ Particularly intellectuals and the Catholic Church adopted this vision and stigmatized the Pentecostal movement. Later, they favored other descriptions and portrayed Pentecostal churches in the media as organizations who exploit the needs of their members by promising miracles. ${ }^{31}$

Also historical Protestant churches that were mostly shaped by the middle class partly adopted the anti-sect discourse and applied it to the Pentecostal movement. ${ }^{32}$ Seeking to distinguish themselves from the new sectarian Protestantism of the lower class, they joined the public opinion about Pentecostalism. Even those who had an affinity for charismatic Protestantism held a critical view. ${ }^{33}$

The anti-sect discourse triggered two reactions on the side of the movement which were especially virulent among its middle class segments: a political mobilization in the form of political parties and interest groups ${ }^{34}$ and a partial adoption of the sect discourse. Threatened by the sect-stigma, Pentecostals sought to attribute the stigma to other religious groups. They attributed the term "sect" to Jehovah's witnesses, Mormons, Pentecostal churches from Brazil, and Afrobrazilian religions. Thus, many Pentecostal churches engaged in a symbolic - and spiritual - war against their religious competitors. Especially Afrobrazilian religions and witchcraft were attacked by some Pentecostal churches as demonic practices. ${ }^{35}$

30 Bastian 1994a: 116; 1997: 21-23; Wynarzcyk 2009a: 179-192; Semán 200o: 161.

$31 \quad$ Frigerio 1998: 443.

32 Wynarczyk 2009a: 198-204.

33 For instance, Deiros, a supporter of the charismatic renewal within the Baptist church writes about the Pentecostal movement that it tends towards a superficial gospel and untrue doctrines: "La evangelización es fuerte, pero superficial. La debilidad ética de los creyentes es consecuencia de esto como también de la carencia de un proceso discipulado integral. La falta de líderes preparados y la incapacidad de entrenar rápidadmene a todos los que hacen falta, fácilmente lleva a doctrinas espúreas y prácticas ajenas a una comprensión neotestamentaria de la fe." (Deiros 1992: 176) Another example is Santos (2003: 234) who criticizes the Pentecostal movement indirectly, identifying it with the concept of prosperity gospel.

34 Wynarzcyk 2009a; 2010; Wynarczyk et al. 1995: 11.

35 Frigerio 1998: 446-450; Wynarczyk 1995; 2009a: 206, 208. In the terminology of Pierre Bourdieu (1971a; 1971b; 1992) one can describe these stigmatization practices as part of a 
From the gos onwards, the attitudes towards Pentecostalism changed slightly. The public discourse became more open with regard to Pentecostalism and its public image improved. ${ }^{36}$ Although Pentecostalism did not become a legitimate religious actor, its social staturs changed from an "intolerable" to a "tolerable" religious deviation. ${ }^{37}$

Yet, at the same time prejudices and reservations still exist. The evangelical movement, and in particular Pentecostalism, are usually associated with the lower class and poverty while their religiosity is perceived as immature and inferior. ${ }^{38}$ Popular explanations for Pentecostal conversions refer to poverty and deprivation, lack of culture, mental problems, and superstition of those who become Pentecostals. Hence, members of Pentecostal churches are indirectly - or sometimes even directly - described as ignorant, mentally instable, and superstitious. ${ }^{39}$ Particularly the urban middle class remains skeptical with regard to the evangelistas. The fact that many Argentineans identify TV programs from the Iglesia Universal del Reino de Dios (IURD) - which they tend to perceive as an exploitation of poor and ignorant people - with the whole evangelical movement does not improve the movement's public image. ${ }^{40}$ Also, secular media coverage contributes to a rather critical image of the evangelical movement. Argentinean sociologist Pablo Semán states that the majority of the media portrays evangelicals as religious fanatics. ${ }^{41}$ Media contributions tend to depict adherents of the movement as impoverished victims of evangelical conversion strategies and point to its alleged otherness from the Argentinean

general struggle for hegemony in the religious field. While Pentecostals are attacked by the Catholic Church and other actors in society, they try to delegitimize their religious competitors in order to establish themselves as the legitimate suppliers of religious "salvation goods" in the Argentinean society. Yet, this struggle for legitimacy not only occurs between the representatives of different religions but also within the same religion where different actors try to establish themselves as the legitimate representation of this religion. Argentinean Pentecostalism is no exception. Pentecostals from different branches fight about legitimacy and the appropriate style of Pentecostalism.

36 Míguez 1998: 120.

37 Frigerio 1998: 446-450, 453-455.

38 Semán 2004: 12-18.

39 Frigerio 1998; Semán 2006a: 217.

40 This is an observation which I made with Argentineans who had only a sparse relationship with members of the movement and therefore little knowledge about Pentecostalism. They tended to identify the movement with images from TV programs from the Brazileros, the Brazilians, as they called the IURD.

Semán 2004: 17. 
society which is experienced as genuinely Catholic. This was the case, for instance, during the evangelical campaign of Luis Palau in 2008 in Buenos Aires. A study from Giménez, Carbonelli and Mosqueira reveals that the Argentinean print media underlines again and again the otherness of the movement. ${ }^{42}$

Another example is the publication of Seselovsky's book “iCristo llame ya! Crónicas de la avanzada evangélica en la Argentina". ${ }^{43}$ The cover of the book, showing Jesus as a comic figure who receives a call on his mobile phone, already indicates that the movement is no longer perceived as dangerous. By contrast, the author wants to invite his readers to cast an ironic glance at the movement and to laugh at it. ${ }^{44}$ Algranti summarizes these tendencies in the following way:

The media coverage of the March 2008 visit by Luis Palau or the book "Christ Calls Now!" are examples of the way in which informal journalism reinforces common prejudices, which are, in turn, sublimated prejudices of a class that uses poor people's religious practices as a mirror to affirm their social status. This negative symbolic capital impacts society, creating a marginalization effect.

ALGRANTI 2010: $49^{45}$

Pentecostals tend to be regarded as desprolijos, untidy and poor people who hold superstitious beliefs. ${ }^{46}$ Thus, the image which associates the movement with "the superstition of the popular masses" and a "culture of poverty" remains. Pentecostalism is depreciated as a lower class culture, as the "uncivilized" Argentina.

42 Giménez et al. 2008. Vast portions of the media discourse appear to be governed by middle class representations of appropriateness especially concerning the practice of religion. Media communication helps to standardize and stabilize these representations. They are experienced as a normal standard due to which, for instance, it is common to consider Pentecostals as abnormal, as something alien to the Argentinean normality. As in the case of the $\mathrm{UK}$, the dominance of the middle class discourse of appropriateness remains widely unacknowledged and leads to a general depiction of lower class culture as deficient. See Reay 1998; 2005b: 141-143; Skeggs 2004; Savage 2003: 536-537.

43 Seselovsky 2005.

44 For a detailed analysis of the book, see Wynarczyk 2005.

45 The original quote is: "El tratamiento mediático de la visita de Luis Palau en marzo del 2008 o el libro Cristo llame ya! son ejemplos de la forma en que el periodismo informal refuerza los prejuicios del sentido común, que son, a su vez, los prejuicios sublimados de una clase que utiliza a las religiones de los pobres como espejo y confirmación de su posición social. Este capital simbólico negativo impacta en la sociedad, produciendo un efecto de descalificación." (Algranti 2010: 49). 
Particularly the educated middle class regard manifestations of popular religion such as Pentecostalism with skepticism and tends to perceive it as socially inferior. ${ }^{47}$ Their negative perception of the movement appears to be partly fed by their rejection of popular culture and a concept of a modernity according to which "premodern" religious beliefs and practices should diminish.

The negative perception of Pentecostalism renders it less likely to turn one's back on Catholicism and become a Pentecostal. Middle class individuals who convert to evangelical Protestantism may face mockery or even discrimination from their colleagues, relatives or friends. The reluctance and disdain of the middle class with regard to Pentecostalism becomes manifest in the social stratification of the movement which will be outlined in the following section.

\subsection{The Social Stratification of the Pentecostal Movement}

As the introduction to Argentina's history in the fourth chapter has already shown, the Pentecostal movement has attracted mostly the lower class. Only since the 199os has Pentecostalism also started to recruit individuals from the urban middle class. However, it is not clear as to what degree the Pentecostal movement has managed to introduce itself into Argentina's middle class. Unfortunately, no study exists which explores the social composition of the Pentecostal movement in detail. Still, there are several studies which refer to the topic and allow some conclusions to be drawn about the social stratification of Argentinean Pentecostalism.

There are two quantitative surveys which were conducted by Conicet researchers and indicate the social position of Pentecostals: the general 2008 Conicet survey and a survey that was conducted in Quilmes, a district in the greater metropolitan area of Buenos Aires.

In addition to questions about the religious belonging, the 2008 Conicet survey also included questions about the interviewees' level of formal education. Figure 4 shows the educational levels of Protestants in comparison to all other respondents. The group of Protestants includes Pentecostals as well as traditional Protestants and other types of non-Pentecostal Evangelicals. ${ }^{48}$ Pentecostals form the overwhelming majority among Protestants. ${ }^{49}$ NonProtestants include all the individuals not included in the Protestant group.

\footnotetext{
47 Semán 2004: 12-18.

48 This group does not include movements such as Jehovah's Witnesses or Mormons.

49 They make up $87.8 \%$ of this group. A total of $9 \%$ of the informants in this survey define themselves as Protestants while $7.9 \%$ of the informants are Pentecostal and form part of the Protestant group. Therefore, $87.78 \%$ of the Protestants in this survey are Pentecostal.
} 
They consist, therefore, of Catholics, Jehovah's Witnesses, Mormons, adherents of Afrobrazilian religions, Buddhists, and individuals without any religious affiliation. ${ }^{50}$

Almost $80 \%$ of the Protestants interviewed have not completed secondary school compared with $60 \%$ of all other individuals interviewed. Around $20 \%$ of Protestants have completed secondary school and only $2.37 \%$ of them have attained a higher education degree (terciario or university). Among non-Protestants, by contrast, almost $30 \%$ hold a secondary school degree and $11 \%$ a higher education degree. Hence, the average formal education of Protestants is significantly lower than that of non-Protestants. The data can be summarized in the following way: the higher the level of education, the less likely it is achieved by a Protestant in comparison to his/her non-Protestant peers. ${ }^{51}$



FIGURE 4 Formal education of Protestants and Non-Protestants in Argentina (BASED ON CONICET 2008)

50 See Conicet 2008. The group of Protestants make up just $9 \%(n=217)$ of all informants while the group of non-Protestants includes $91 \%$ of the informants of the total sample of $\mathrm{n}=2403$.

$5^{1}$ As pointed out above, the observed group embraces Pentecostals and historical Protestants. Taking into account that historical Protestants tend to be from the middle class and generally achieve a higher level of education than Pentecostals, it can be expected that the historical Protestants have an elevating effect on the statistics. Thus, analysing the Pentecostals alone, this group might even have slightly lower levels of education in comparison to the non-Pentecostals. 
The second quantitative study, which was conducted by the Conicet points to the high presence of Pentecostals in lower class neighborhoods of Quilmes. The study reveals that the percentage of Protestants in lower class neighborhoods of Quilmes is $22 \%$, while the average percentage of Protestants in Quilmes is $10.2 \% .^{52}$

Wynarczyk comes to a similar finding by studying the inscriptions in the Registro Nacional de Culto (registro): the percentage of non-Catholic cults inscribed in the registro - mainly Pentecostal churches - is significantly higher in the poorer suburban areas of Buenos Aires than in the city of Buenos Aires, which is on average better off than its surrounding areas. ${ }^{53}$ Thus, the sociogeographical distribution of Pentecostalism indicates that the proportion of Pentecostals among lower classes is significantly higher than among middle and upper classes. ${ }^{54}$ Wynarczyk refers to another quantitative study: an unpublished study he completed with Johns in 1996. For this study both conducted an empirical survey with a sample of 395 cases in the middle class neighbourhoods of Palermo and Belgrano in Buenos Aires. It turned out that only 3.7\% of those holding a higher education degree defined themselves as Protestants. However, in this case, one has to take into account the fact that the group of Protestants also contains historical Protestants who tend to hold higher education degrees than Pentecostals. Thus, the average percentage of Pentecostals among Argentineans holding higher education degrees will even be lower. ${ }^{55}$

Another study was conducted by Pablo Semán in the gos in the lower class neighbourhood Partidos de Lomas de Zamora where he studied 206 families. $19.19 \%$ of his informants were Protestant, mainly from small Pentecostal churches in this neighbourhood. Interestingly, Semán's study comes to a percentage of Pentecostals in lower class neighbourhoods very similar to that of the study completed by the Conicet in Quilmes. ${ }^{56}$ Finally, Míguez refers to a study conducted by Roemers at the beginning of the gos which underlines the predominance of the lower class among Pentecostals. ${ }^{57}$

\footnotetext{
$5^{2} \quad$ See Esquivel, Juan et al. 2001.

53 Wynarczyk 2009b: 64-65.

54 See also Mallimaci 1999: 86-87; Wynarczyk et al. 1995: 7 .

55 The data is based on a study from Wynarczyk and Johns (1996). I had no direct access to the study. The information that I cite here is taken from Wynarczyk 2009a: 53-55, 170-171.

56 Semán 2010.

57 Míguez 2001: 78. The study from Roemers was cited in the following way: "Roemers, G. (1992) Creyentes (ma non tropo), pag. 30". Yet, it was not possible for me to get personal access to the study.
} 
In total, the data indicates that Pentecostalism is more prevalent among the lower than the middle class: while around $20 \%$ of the lower class are Pentecostal, in the middle class the proportion remains significantly below $5 \%{ }^{58}$ Wynarczyk summarizes these findings in the following way: the higher the social sector, the lower the proportion of Pentecostals in this sector. ${ }^{59}$

In total, the impact of the movement on the middle class remains modest. In particular, members of the middle class with higher education degrees form a small minority in the movement. The movement has so far maintained its lower class character. Similar tendencies have also been observed in other Latin American countries. ${ }^{60}$ The lower class class bias of the Pentecostal movement raises the question of why Pentecostalism barely attracts the middle class. In the following, I will submit some explanations for the class bias of Pentecostalism.

\subsubsection{Depriving the Deprived: Pentecostalism as a Consequence of Deprivation}

Various attempts have been made to explain the lower class bias of the Pentecostal movement. The most widespread in the public sphere - which is equally present among scholars of religion - are perhaps deprivation approaches. The deprivation approaches posit that deprivation creates a context conducive for Pentecostalism which is thought to serve the function of a survival (or compensation) strategy for the deprived.

Predominantly attracting deprived and vulnerable individuals, it can be suggested that the social bias of the movement is related to the problems of its adherents. Suffering from diverse afflictions and lacking other means to

$5^{8}$ Besides these quantitative studies, there are several ethnographic studies which illustrate the occurrence of the movement in the lower class of Argentinean society. Analogically to the quantitative surveys, the ethnographic studies indicate that Pentecostalism is mainly a lower class movement. Each of these inquiries consists of a case study which focuses in general on one church. Míguez $(1998,2001)$, for instance, studied a Pentecostal church in a lower class neighborhood, Partido de Merlo. Soneira (1994) studied the church Dimension de Fé which is situated on the border of the city of Buenos Aires. Moreover, there are several studies on the church Ondas de Amor y Paz (Wynarczyk 1989; Tort et al. 1993) and studies from Semán $(1997,2000)$ about the occurrence of Pentecostalism in popular religion.

59 Wynarczyk 2009a. 171. See also Wynarczyk 2010: 19.

60 Anderson 2004: 59, 282; Bastian 1997: 59-72, 61-68, 71, 139-140; Burdick 1993a: 79, 85; Chesnut 1997: 17; 2003: 39-43; Deiros 1992: 175; Fernandes 1992; Freston 1998: 338, 341-342; 1999: 145-146; Höllinger 2006: 267-269; Hunt 2002a; Lehmann 1996: 210-214; 2003: 492; Mariz 1994: 35; Martin 1990: 53; 202; 2002: 1, 20; 78; Parker 1996:154-155; Schäfer 2009a: 48; Stewart-Gambino et al. 1997: 241. 
overcome their suffering, they are likely to seek a solution in the sphere of religion. Particularly Pentecostalism is perceived as offering means of easing suffering or even solving problems, such as the famous IURD slogan suggests: "Stop Suffering!" From this perspective, Pentecostalism is regarded as a remedy for the sufferings created by deprivation. ${ }^{61}$ Deprivation approaches imply an almost direct causality between deprivation and the choice of a specific solution: particular living-conditions marked by deprivation and poverty are conceived of as leading those who are affected by them to Pentecostalism. Pentecostalism appears as a result of the living-conditions of the deprived. Therefore, deprivation approaches seem to deprive the deprived of an autonomous religious culture: they reduce the religiosity of the deprived to a product or side-effect of their deprivation.

It is evident that the experience of deprivation can stimulate the search for a solution which may indeed end up in the main hall of a Pentecostal church. Regarding the motives that individuals communicate for their affiliation with a Pentecostal church, there is some evidence for deprivation approaches. Many Pentecostals state that they first went to a Pentecostal church due to suffering from a problem. ${ }^{62}$ Lower class actors may try to find solutions for their daily problems in Pentecostal churches. However, the bare fact of deprivation alone does not explain why those who are affected by deprivation turn to religion and appear to prefer specific types of religion in order to ease their suffering. ${ }^{63}$

61 The capacity of Pentecostalism to help individuals cope with poverty-related problems was prominently illustrated by Chesnut (1997) and Mariz (1994) for the case of Brazil (see for Africa Hesuer 2013). Others like Maristoca (1994: 13) and Bastian (1997: 139-140, 200-203) point out that Pentecostalism offers a new form of social participation and integration for those who are deprived of other means of integration (see also Ruuth 2001: 122-123). For the case of Argentinean Pentecostalism particularly Algranti (2007b: 26) and Míguez (2005: 10) point to its capacity to help individuals in dealing with the social transformations in the country. Yet, the outcomes of Pentecostalism as a survival strategy may be limited as Míguez (1998, 2001) indicates.

62 Algranti 2010: 153; Frigerio 1999: 72-74; Míguez 1998: 119-122; 2001: 80-83.

63 The approaches disregard the fact that every problem may correspond to a variety of solutions which can be both religious and non-religious. The bare fact of marginal living conditions does not explain why individuals choose Pentecostalism to deal with their problems and not a different cultural option. Numerous individuals who suffer from similar problems do not choose Pentecostalism as a strategy to deal with their problems. This raises the question of how the absence of a conversion to Pentecostalism in these cases can be explained by deprivation approaches. Also, with regard to the low impact of Pentecostalism in the middle class, deprivation approaches do not clarify why the middle class does not tend to choose Pentecostalism as a solution strategy when facing problems similar to those driving the lower class to Pentecostalism: family disruption, depression, 


\subsubsection{Cultural Explanations of Pentecostal Growth among the Lower Class}

Other explanations for the growth of Pentecostalism among the lower class refer to cultural factors. ${ }^{64}$ Argentinean researchers like Semán, Wynarczyk and Míguez argue that the Pentecostal movement appropriated and re-organized religious ideas and practices which already existed in Latin America's lower classes. In this view, the expansion of Pentecostalism among the lower class is not a pure result of the deprivation of lower class individuals. Instead, the success of Pentecostalism is a product of its ability to re-organize pre-existing socio-cognitive patterns of the lower classes into an appealing religious option which offers convincing schemes of interpretation and solutions for deprivation-related problems. ${ }^{65}$ This approach draws attention to the underlying cultural dimension of the relationship between Pentecostalism and social stratification. Succinctly, the lower class appeal of Pentecostalism is explained by a match between popular (lower class) culture/religion and Pentecostalism.

(...) the growth of Pentecostalism can be explained by the ability of these groups to mobilize and use the existing cultural concepts of those affected by various forms of poverty

SEMAN 2000: $158^{66}$

Argentinean Pentecostalism integrates important elements of the culture and religiosity of the lower class. It exhibits a festive and emotional style, involves a cosmological world view supposing constant supernatural interventions, and stresses supernatural means to improve daily life. Therefore, Argentinean Pentecostalism can be described as a manifestation of popular religion and an integral part of nowadays popular culture in Argentina.

drug and alcohol abuse and particularly health problems. For further criticism of these approaches, see also McCloud 2007a; Parker 1996:156; Semán 2000.

64 See also Bastian 1994a: 122-124; Parker 1996:148.

65 See Míguez 1998: 83-74, 141; Séman 1997: 139; Wynarczyk et al. 1995: 7. Pentecostalism is conceived of as a rearrangement of religious concepts that already exist in the social memory and cultural habits of the lower class. This pre-existing religious universe may manifest itself in a variety of religious practices and beliefs, as Séman (2000: 167) points out. Examples for other manifestations of this popular religious universe are popular Catholicism and Afrobrazilian religions.

66 The original quote is: „(...) el crecimiento del pentecostalismo puede explicarse por la capacidad que tienen estos grupos para movilizar y combinar los supuestos culturales preexistentes de los grupos afectados por diversas formas de pobreza“(Séman 2000: 158). 
In total, the lower class appeal of Pentecostalism can be explained by a combination of cultural approaches and deprivation theories. Taking the deprivation and cultural approaches together, one can assume that different forms of suffering create a stimulus for the search for a solution while cultural affinities and worldviews (popular religion) may guide the search for a solution in the direction of Pentecostalism. ${ }^{67}$ The cultural proximity of the lower class to popular religion produces an affinity for Pentecostalism which transforms Pentecostalism into an appealing solution for different types of deprivation-related suffering.

\subsubsection{The Middle Class Mismatch}

This explanation still remains incomplete somehow: in order to explain the class bias of Pentecostalism, also its low success among the educated middle class has to be taken into account. In analogy to the explanation of its success among the lower class, one can contend that its low appeal to the educated middle class is caused by a mismatch between Pentecostalism and the representations of the middle class. There are basically two ill-fitting aspects which seem to be the origin for its low degree of success among the educated middle class: (1) the negative status and conception of Pentecostalism and (2) the cultural patterns of Pentecostalism. Both - the negative conception and the cultural patterns of Pentecostalism - do not fit well with what is regarded as appropriate, legitimate and desirable within the middle class.

As shown above, the social conception of Pentecostalism remains negative. Pentecostalism tends to be mocked and is described as a phenomenon remote from the "real" Argentinean identity. Even though Pentecostals are more tolerated today than in the 1980 s, their religious and public legitimacy remains rather weak. Especially among the educated middle class prevail views which regard Pentecostalism as an immature and pre-modern expression of popular religiosity. Moreover, Pentecostalism is depicted as a lower class religion in Argentinean society. Pentecostals are portrayed as deprived lower class individuals who struggle with poverty and become victims of the persuasion techniques of Pentecostal preachers. Being portrayed as a religion of the marginalized does not improve its appeal to the middle class which tries to avoid being identified with a lower class practice, a practice of the negros that reflects the precarious "culture of poverty".

In addition, the cultural patterns of Pentecostalism do not fit well with the representations of the middle class: the fire of the Spirit, moments of collective ecstasy, dancing in the Spirit, people trembling, crying and dropping to the

67 See also Míguez 1998: 121. 
ground, others shouting loudly "hallelujah", practices of faith healing casting out demons, prophecy, prayers in tongues, miracles and divine healings - it seems like educated middle class Argentineans could not be in a less fitting place. The holistic worldview, the expressivity and emotionality of its church services as well as the alleged fundamentalism and anti-intellectualism of Pentecostalism do not fit with a middle class who aspires to be cosmopolitan, tidy, sober, highly educated, rational, and scientific in its reasoning. From the viewpoint of an educated middle class which celebrates its attachment to the European ideology of modernity, the practices and beliefs of Pentecostalism appear pre-modern, superstitious, and uncivilized.

The fact that Pentecostalism is mainly a lower class movement does not improve its possibilities of reaching the middle class. Since initial interactions with the Pentecostal movement are generally created through social networks of individuals with close social bonds, the movement - being mainly composed of lower class individuals - faces difficulties reaching middle class individuals. ${ }^{68}$

In sum, the lower class bias of Pentecostalism is not only due to a cultural fit between Pentecostalism and popular religion, but also due a mismatch between Pentecostalism and representations of the middle class. ${ }^{69}$ Within a middle class in which popular religion is not absent but not well accepted, Pentecostalism does not constitute the most appropriate religious option.

\subsection{From Conformance to Deviation: Experiencing Inappropriateness}

(...) an individual who might have been received easily in ordinary social intercourse possesses a trait that can obtrude itself upon attention and turn those of us whom he meets away from him, breaking the claim that

68 Moreover, middle class individuals engaging in Pentecostalism often face trouble finding class peers who share similar cultural affinities in the movement, as some middle class informants described in the interviews. Finally, the lower class bias of the movement creates a lower class image which is not appealing to the educated middle class. Ironically, being a lower class movement appears to contribute to the lower class bias of the movement. Consequently, the lower class bias appears to be at the same time both a cause and a product of the lower class bias.

69 Particularly public discourses and the resulting conceptions of Pentecostalism appear to contribute to this ill fit and hinder educated middle class Argentineans from passing through the entrance of a Pentecostal church. 
his other attributes have on us. He possesses a stigma, an undesired differentness (....).

GOFFMAN 1963: 5

The picture sketched out so far is a picture of religious practices that fit to the class representations: it is a generalized picture of individuals who dedicate themselves to religious options that match their class representations. This picture fits well to the common conception of a lower class deeply involved in popular religion and Pentecostalism, and a middle class avoiding the "superstitious" religious practices of the popular masses.

However, the empirical activity of individuals does not always correspond to the prevailing social representations. The practices and attitudes of individuals may be mismatched with the social representations of the group to which they belong: one can find educated middle class Porteños who practice popular religion as well as lower class Argentineans who reject popular religion. Contrary to what concepts of popular religion seem to suggest, considerable sections of the lower class communicate doubts with regard to the possibility of supernatural interventions and have a comparatively low affinity for popular religion and Pentecostalism. ${ }^{70}$ Also among the educated middle class there is non-conformance: highly educated professionals who engage in witchcraft, Afrobrazilian cults or Pentecostalism. They deviate to some degree from the social expectations and cultural aspirations of the middle class. Highly educated middle class Pentecostals are examples of these deviations. Their religious choice does not fit well with the representations of the middle class.

A conversion to Pentecostalism can have deep consequences for the social life of the middle class convert. The new Pentecostal identity may lead to experiences of uneasiness, rejection or open discrimination in the social environment of the convert. Often, tensions arose in the social environment of middle class interviewees: friendships, family and work relations suffered. Longstanding friendships fell apart, as in the case of Alberto. When he told his friends about his conversion to Pentecostalism they called him crazy and brainwashed. Only one of his old friends maintained contact with him. In some cases, interviewees faced tensions at work. Andrea, for instance, was harassed by her boss due to her religious affiliation. Other interviewees from middle class families experienced tensions with their relatives who had

$70 \quad$ Míguez 1998: 121, 141. Nevertheless, the general tendency towards popular religion appears to be more pervasive among the lower class than the middle class. 
negative perceptions of Pentecostalism. One example is Horacio: after his conversion to Pentecostalism, Horacio lost contact with his father who completely rejected Horacio`s decision to become Pentecostal and refused to speak to him for years.

On one occasion, an interviewee related to me how he tried to rescue his wife from Pentecostalism. Much to Carlos' chagrin, his wife had converted to Pentecostalism. In order to "rescue" her, he accompanied her to the Pentecostal church:

(...) the first time I went, I saw a bunch of crazy people. I saw them and I laughed, I laughed hysterically...'They are all crazy!' I said to myself. They were very passionate Pentecostals. They would come over to me and say "I'll pray for you," and I would send them away saying, "No, thank you," because I thought they were all crazy. Of course I wanted to get Silvia out of there, (...)

INTERVIEW CARLOS

His first reactions illustrate the middle class rejection of the movement. Despite having experimented with different kinds of alternative religions before this visit, he experiences the movement as a "manga de locos", a bunch of crazy people, which he ridicules and from which he has to rescue his wife. However, after accompanying her several times to the church service his attitude changes. He starts to accept his wife's new religious affiliation and finally also converts to the movement. ${ }^{71}$

The tensions between representations of the middle class and Pentecostalism also become evident during the interviews I conducted: middle class Pentecostals laugh loudly about what they see when watching videos of Pentecostal churches and their practices of faith healing. They seem to be embarrassed by Pentecostalism, their own religious faith, and seek to differentiate themselves from what they see. This is accomplished partly by outright criticism and mockery of the style of Pentecostalism or more subtly by including mild forms of self-criticism. Thus, Alejandra, a lawyer, states: "Somos un poco desprolijos."72 She describes her religious community, including herself, as untidy and laments that the Pentecostal movement does not correspond to what is perceived as prolijo (tidy). This comment illustrates the conflict

\footnotetext{
71 In general, middle class interviewees were very aware of their exceptional status: they know that they form a minority within the movement as well as among the educated middle class. They lamented the low proportion of professionals in the movement. 
between the middle class ideal of tidiness and the conception of the Pentecostal movement. Indirectly, she sets tidiness as a general standard to which the movement should adapt itself and portrays her religious practice as deficient in comparison to this standard.

Criticisms which regret the non-conformance of the movement to some "civilized" standards and call, directly or indirectly, for some kind of adaptation to these standards illustrate the tension between the movement and what is regarded as appropriate within the Argentinean middle class. Another example is Laura who states that she dislikes "el tumulto" (the turmoil) in Pentecostal churches because the turmoil would lead non-Pentecostals to perceive them as crazy. ${ }^{73}$ She explains later in the interview that she is afraid of bringing her ex-fellow students to her church and feels embarrassed due to the inadequate behavior of her peer members. Another interviewee, watching a video with a pastor shouting into the microphone, states:

You can't bring anyone here, like a colleague or someone you are dating, because they would say to you: 'Everyone is loony here. They are all crazy. What is this?' Do you know what I mean?

INTERVIEW CAMILA

Camila criticizes that it is not possible to bring non-Pentecostal peers to this type of church because its practice would be perceived as crazy. These statements from middle class Pentecostals illustrate that they have a clear idea about what is experienced as normal and appropriate by their middle class peers. They know that Pentecostalism may violate the middle class standards of appropriateness. They view and evaluate Pentecostalism from the viewpoint of their non-Pentecostal class peers and contemplate what they would regard as inappropriate. Laura and Camila appear to almost rationally calculate that an "unadapted" religious practice will lead them to uncomfortable situations in which they risk embarrassment. Instead of facing shame they want their religious practice to be socially acceptable.

In situations in which the boundaries of what is perceived as appropriate are crossed, middle class Pentecostals are afraid of being identified with "inappropriate" practices. They are afraid of losing face with their middle class peers and being regarded as different from the "decent middle class". Being a Pentecostal means potentially crossing the fragile symbolic boundaries of the middle class.

73 Interview Laura. 


\section{$5 \cdot 4 \quad$ Summary}

The aim of this chapter was to present an overview of Argentinean Pentecostalism and to discuss its relationship with social class order in general and the middle class in particular.

The chapter began with a brief overview of the diversity and competition within Pentecostalism in Argentina. Despite the diversity of the movement, there are some institutions that unify evangelical Protestantism such as evangelical umbrella organizations, theological institutes, and evangelical mass events. Although these institutions fulfill a representative function vis-à-vis Argentinean society, they represent only a fraction of the movement. The majority of smaller Pentecostal churches, predominantly located in lower class neighborhoods and slums, are not represented by these institutions. Therefore, the institutions constitute a formal circle of evangelical Protestantism from which many churches are excluded. The endeavors of these institutions to improve the public image of Pentecostalism seem to have had - together with the massive expansion of Pentecostalism throughout the population - a softening impact on existing prejudices against Pentecostals. The public image of Pentecostalism has somewhat improved from that of a dangerous and intolerable sect aggressively invading Argentina to that of a tolerable religious deviation. Nevertheless, stigmatization and mockery remain prevalent. Pentecostalism tends to be portrayed as a movement to which the "downtrodden and ignorant" convert and at which people can laugh. The continuing stigmatization of the movement has an impact on its popularity within the middle class and contributes to the lower class bias of Argentinean Pentecostalism. Exploring the social stratification of the Pentecostal movement, it becomes evident that Pentecostalism remains predominantly a lower class movement in Argentina. It was argued that the lower class bias of Pentecostalism is related to (1) the fit between Pentecostalism and popular culture and religion and (2) the mismatch with social representations of the middle class. A religious practice that implies miracles, speaking in tongues, practices of faith healing, and a highly expressive and emotional atmosphere does not fit well with the representations of a middle class which aspires to be sober, modern, European, rational, decent, and well educated. Nevertheless, there is a small group of highly educated middle class porteños that is involved in Pentecostalism. Their religious practice may be experienced by peers as inappropriate and can create tensions in their social relationships. Given these tensions, their presence in the movement raises the question of how they became Pentecostal. How do middle class actors come to choose such an "inappropriate" religious option? This question will be tackled in the following chapter. 